\title{
NOTES ON THE PEPINENSIS GROUP OF THE CRAB SPIDER GENUS EBO (ARANEAE: THOMISIDAE)*
}

\author{
By Norman I. Platnick \\ Museum of Comparative Zoology \\ Cambridge, Mass.
}

Through the courtesy of Mr. Donald J. Buckle, I have recently had the opportunity to examine a series of crab spiders from Saskatchewan representing a new species of $E b o(E b o)$. As this genus has recently been revised, an isolated description of the new species seemed warranted.

The Saskatchewan specimens are most closely allied to Ebo pepinensis Gertsch, and will key out to that species in the published key (Sauer and Platnick, 1972, p. 37), which should be emended as follows:

Ioa. Carapace pale yellow with scattered dark circular markings; legs pale yellow, without dark fleckings; embolus short (1972, Figs. 13, I4); spermathecae as in 1972, Fig. 20; known only from the south central states

punctatus Sauer and Platnick

rob. Carapace orange-brown with dark fleckings; legs usually with dark fleckings; embolus long (Figs. I, 4); spermathecae as in Figs. 3, 6 I I

Ira. Embolus broadly curved, middle loop of duct far from descending loop (Fig. 4); retrolateral tibial apophysis broad, serrate (Fig. 5); spermathecae separated by their width (Fig. 6) ; widely distributed ........... pepinensis Gertsch

Irb. Embolus distinctly angular, middle loop of duct near decending loop (Fig. I) ; retrolateral tibial apophysis long, narrow, not serrate (Fig. 2); spermathecae separated by less than half their width (Fig. 3); known only from Saskatchewan bucklei n. sp.

\section{Ebo bucklei n. sp.}

Figs. I-3

TYPES. Holotype male, allotype female from Saskatchewan ( $5 \mathrm{mi}$. NE of Saskatoon, 6-13 July 1967, E. Gorin) deposited in the Museum of Comparative Zoology. Twenty-two male and nine female paratypes from the same locality, various dates.

*This investigation was supported in part by Public Health Service Grant A1-01944. 

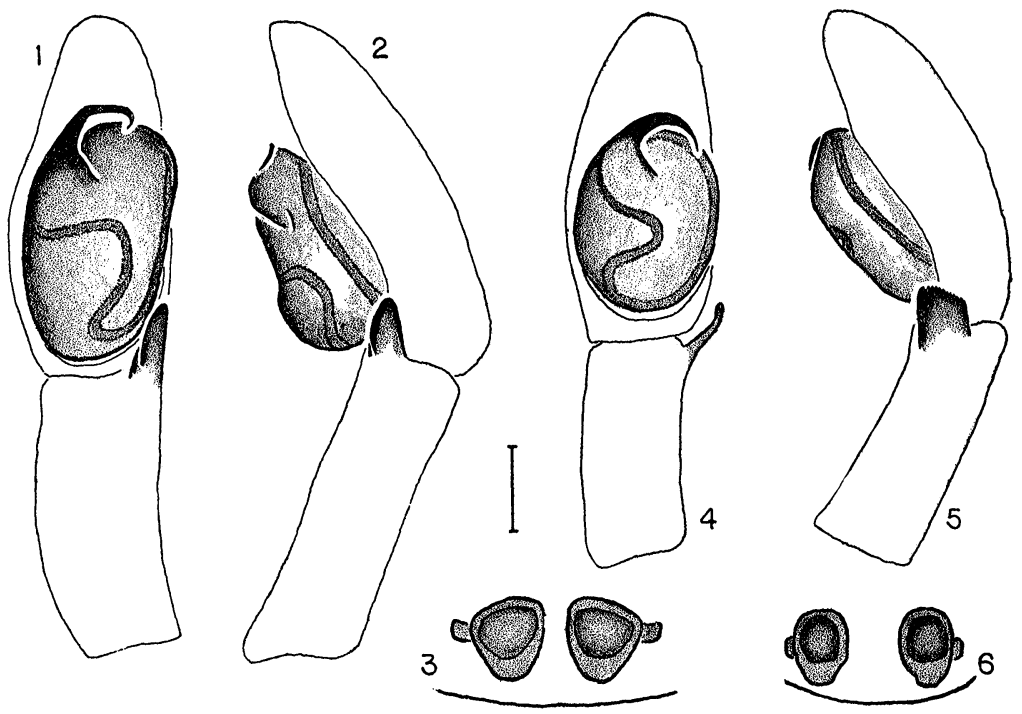

Figs. 1-3. Ebo bucklei n. sp. 1. Male, left palpus, ventral view. 2. Retrolateral view. 3. Female, spermathecae, dorsal view (fertilization tubes omitted).

Figs. 4-6. Ebo pepinensis Gertsch. 4. Male, left palpus, ventral view. 5. Retrolateral view. 6. Female, spermathecae, dorsal view (fertilization tubes omitted). (Scale line $0.1 \mathrm{~mm}$ )

MALE. Total length $2.75 \pm 0.18 \mathrm{~mm}$; carapace $\mathrm{I} .29 \pm 0.07 \mathrm{~mm}$ long and $\mathrm{r} .4 \mathrm{O} \pm 0.09 \mathrm{~mm}$ wide; femur II $2.43 \pm 0.14 \mathrm{~mm}$ long (23 specimens). Carapace orange-brown with dark fleckings and a network of dark reticulations from the lateral edges almost to the thoracic groove. Legs with irregular reddish-brown fleckings. Abdomen pale brown with dark cardiac mark and irregular fleckings forming vague chevrons and posterolateral stripes.

Palpal segments with irregular fleckings, as in Figs. I, 2.

FEMALE. Total length $3.88 \pm 0.43 \mathrm{~mm}$; carapace $\mathrm{I} .44 \pm 0.12$ $\mathrm{mm}$ long and $\mathrm{I} .59 \pm 0.10 \mathrm{~mm}$ wide; femur II $2.38 \pm 0.10 \mathrm{~mm}$ long ( 10 specimens). Coloration as in male.

Epigynum typical for the genus. Spermathecae as in Fig. 3; minute, unsclerotized fertilization tubes not drawn.

RANGE. Known only from the type locality.

COMMENTS AND DIAGNOSIs. Ebo bucklei is most similar to $E$. pepinensis Gertsch, but may be distinguished by the characters listed 
in the key and illustrated in Figs. I-6. Mature males of E. bucklei have been taken from late May through late July; mature females from late June through early August.

The species is named in honor of Mr. Donald J. Buckle, who first brought it to the author's attention.

\section{Literature Cited}

Sauer, R. J. and N. I. Platnick.

1972. The crab spider genus Ebo (Araneida: Thomisidae) in the United States and Canada. Can. Ent. 104: 35-60. 

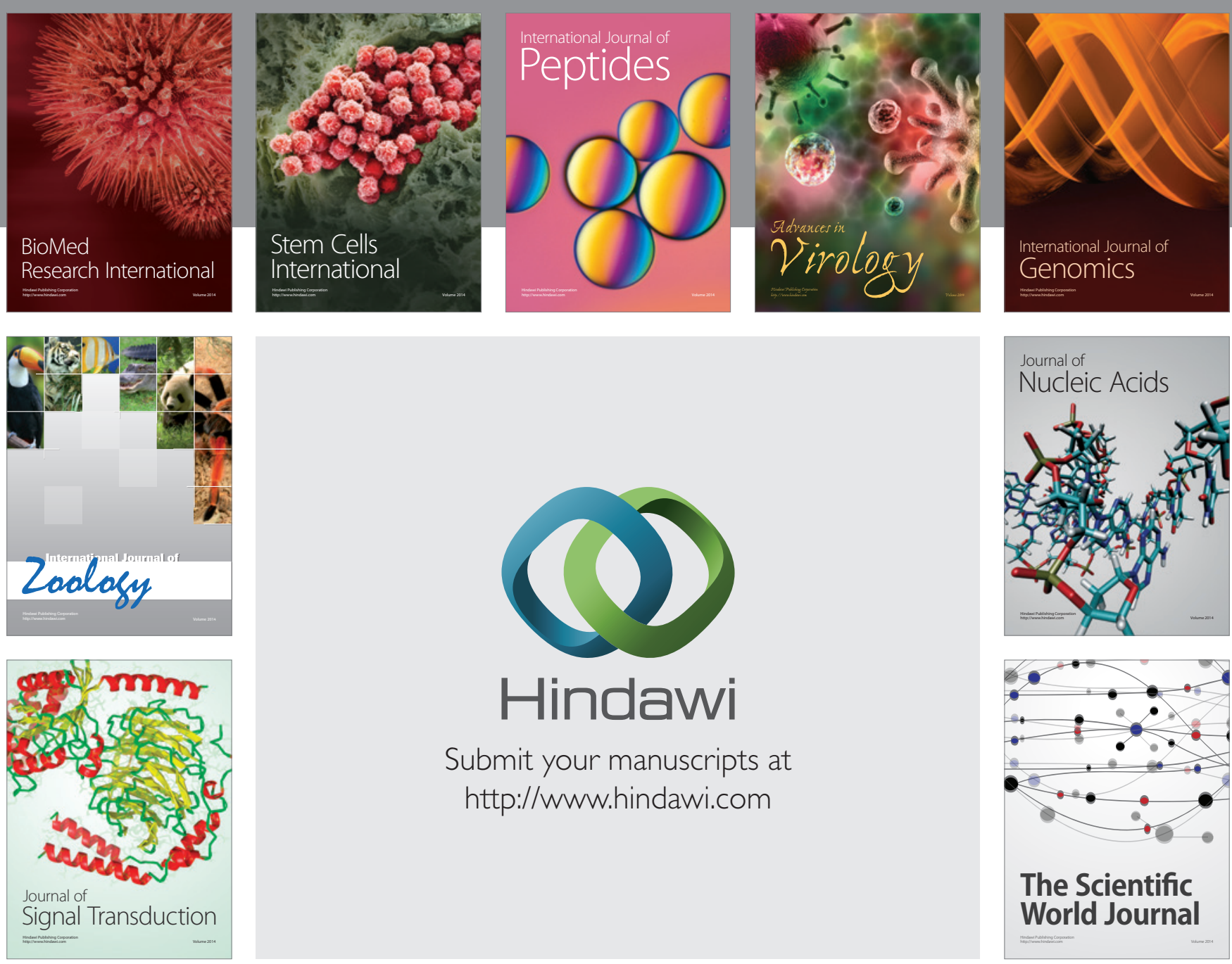

Submit your manuscripts at

http://www.hindawi.com
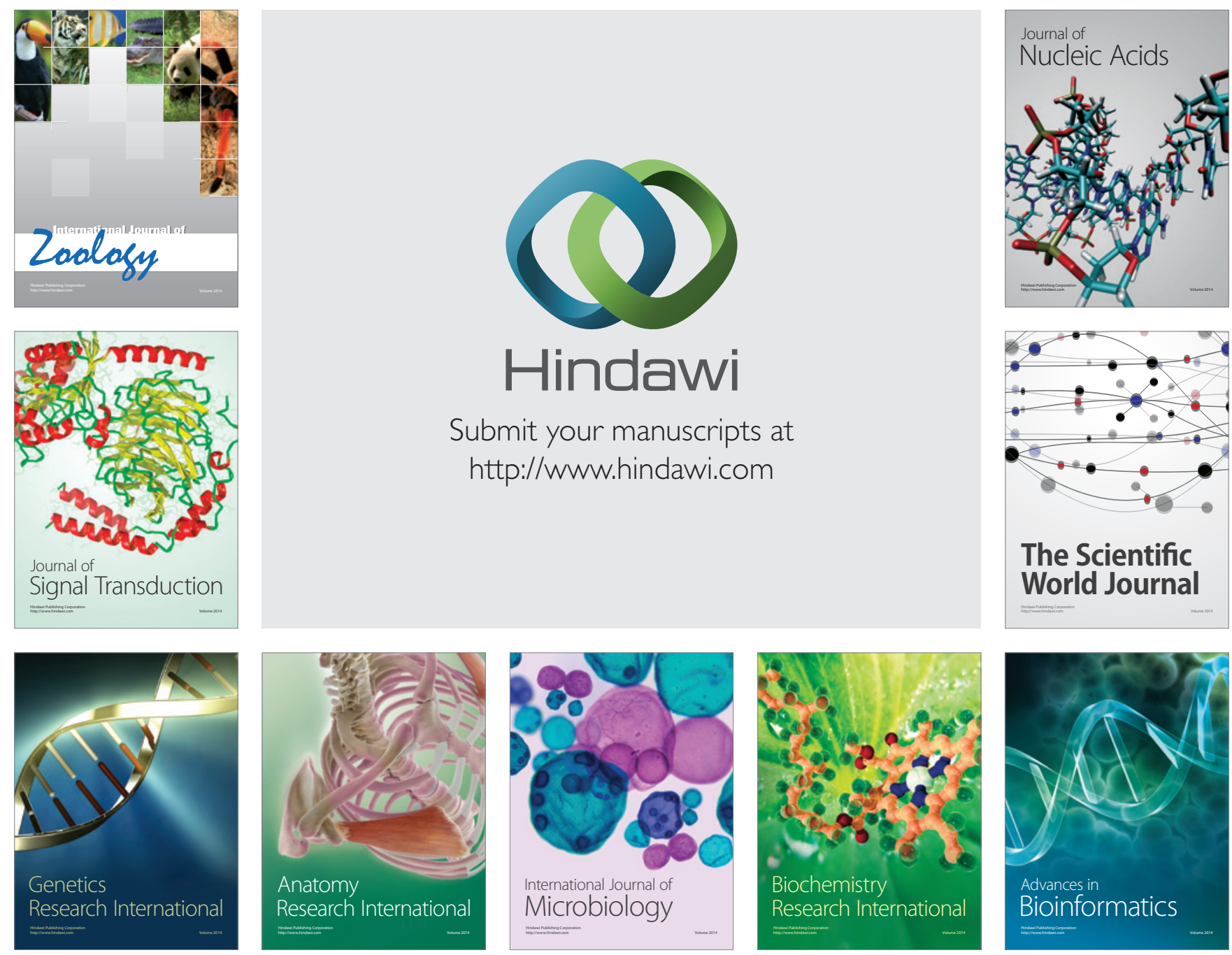

The Scientific World Journal
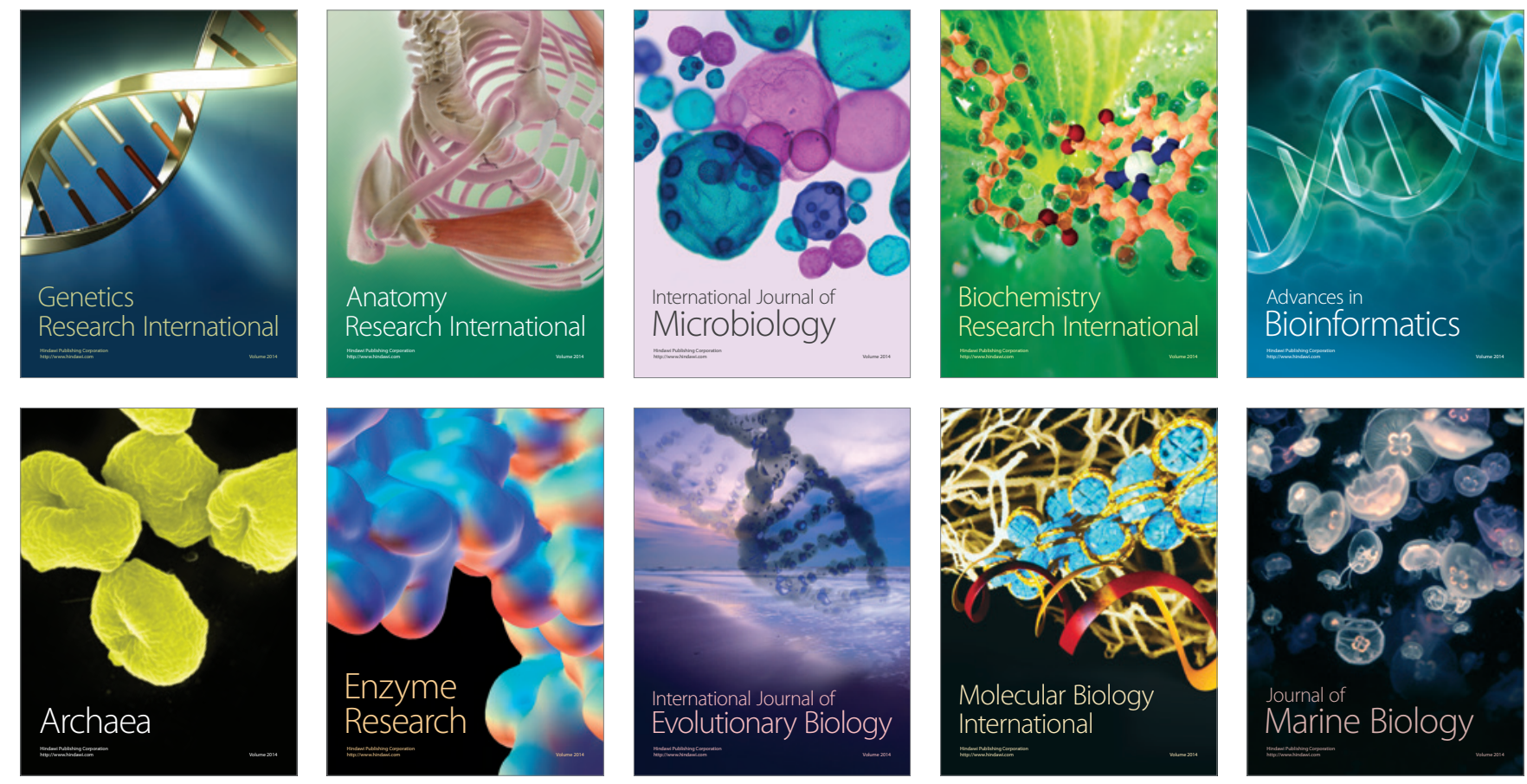